BETTER BUSINESS BY PHONE 


\title{
Better Business by Phone
}

A guide to effective telebusiness management

\author{
Valerie O’Dea
}

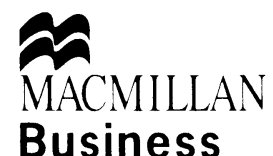




\section{(C) Valerie O'Dea 1998}

All rights reserved. No reproduction, copy or transmission of this publication may be made without written permission.

No paragraph of this publication may be reproduced, copied or transmitted save with written permission or in accordance with the provisions of the Copyright, Designs and Patents Act 1988, or under the terms of any licence permitting limited copying issued by the Copyright Licensing Agency, 90 Tottenham Court Road, London W1P 9HE.

Any person who does any unauthorised act in relation to this publication may be liable to criminal prosecution and civil claims for damages.

The author has asserted her right to be identified as the author of this work in accordance with the Copyright, Designs and Patents Act 1988.

First published 1998 by

\section{MACMILLAN PRESS LTD}

Houndmills, Basingstoke, Hampshire RG21 6XS

and London

Companies and representatives

throughout the world

ISBN 978-0-333-66909-9 ISBN 978-1-349-14195-1(eBook) DOI 10.1007/978-1-349-14195-1

A catalogue record for this book is available from the British Library.

$\begin{array}{rrrrrrrrrr}10 & 9 & 8 & 7 & 6 & 5 & 4 & 3 & 2 & 1 \\ 07 & 06 & 05 & 04 & 03 & 02 & 01 & 00 & 99 & 98\end{array}$

Copy-edited and typeset by Povey-Edmondson

Tavistock and Rochdale, England 
This book is dedicated to the memory of Pauline Malindine

an excellent telebusiness trainer and sadly missed friend 


\section{Contents}

List of Tables and Figures $\quad$ xi

Preface xii

Acknowledgments xiv

Part I Practical Telebusiness and the Company Plan

1 Telebusiness and the Company Plan 3

What is telebusiness?

Who should read this book?

Marketing strategy $\quad 4$

Relationship, direct and database marketing $\quad 6$

$\begin{array}{ll}\text { Planning } & 6\end{array}$

$\begin{array}{lr}\text { Telemarketing applications } & 8\end{array}$

$\begin{array}{ll}\text { Investment } & 15\end{array}$

$\begin{array}{ll}\text { Image } & 16\end{array}$

$\begin{array}{ll}\text { Telemarketing strategy and plans } & 17\end{array}$

$\begin{array}{ll}\text { What do we wish to monitor? } & 17\end{array}$

$\begin{array}{ll}\text { Telemarketing and business processes } & 18\end{array}$

2 Telebusiness and the Product or Service 20

Voice and data choices $\quad 20$

Software functions and features $\quad 22$

In-house or outsourced?

Telemarketing from a database $\quad 24$

Telemarketing to the masses is 'old hat' 24

Customer-loyalty and retention through telemarketing 25

Brand building and telemarketing 26

3 Telebusiness, the Sales Team and the Customer 27

$\begin{array}{ll}\text { Integration } & 27\end{array}$

Relationship marketing $\quad 27$

The partnership approach 28

Major account management $\quad 29$

Problem analysis and prevention $\quad 30$

Major account analysis $\quad 30$ 
$\begin{array}{ll}\text { Partnership solutions } & 31\end{array}$

The customer's view $\quad 32$

Our view of the partnership $\quad 33$

$\begin{array}{ll}\text { Loyalty schemes } & 34\end{array}$

Data sources and management $\quad 34$

$\begin{array}{ll}\text { Marketing database activities } & 36\end{array}$

$\begin{array}{ll}\text { Marketing database evaluation } & 38\end{array}$

$\begin{array}{ll}\text { Product life-cycle } & 39\end{array}$

Field sales needs $\quad 40$

Information flow $\quad 43$

Part II Practical Telebusiness and the Management Plan

4 Telemarketing or Telesales? 47

Where do I start? $\quad 47$

Call centres $\quad 48$

Sales office automation $\quad 49$

How does automation work? $\quad 50$

CASM and ISM systems 51

The importance of integration $\quad 52$

Project management $\quad 54$

Telebusiness personnel $\quad 56$

5 Customer Service Policy and Internal Communication 58

Customer service strategy $\quad 58$

$\begin{array}{ll}\text { Total team integration } & 60\end{array}$

Management attitudes 61

Communication $\quad 66$

Internal auditing $\quad 67$

Empowerment $\quad 69$

A simple solution $\quad 70$

Teamwork $\quad 71$

Loyalty through customer service $\quad 73$

Understanding change $\quad 74$

Quality issues $\quad 76$

6 Recruiting and Targeting Telebusiness Personnel 80

$\begin{array}{ll}\text { Person specification } & 80\end{array}$

Lack of maturity? $\quad 81$

Analysing the job and the person $\quad 82$

Interviewing $\quad 84$

Easy steps to good interviewing $\quad 89$ 
$\begin{array}{ll}\text { Psychological testing } & 90\end{array}$

Performance standards $\quad 90$

Performance review $\quad 92$

Targeting $\quad 96$

Incentive schemes $\quad 98$

7 Managing and Training Telebusiness Personnel 101

The role of the telebusiness manager 101

$\begin{array}{ll}\text { Motivation } & 101\end{array}$

Training and coaching 108

Short- and long-term training $\quad 114$

$\begin{array}{ll}\text { Assessment criteria } & 115\end{array}$

Value-for-money training $\quad 118$

How long should a call take? 119

$\begin{array}{ll}\text { Meetings } & 120\end{array}$

Time management $\quad 123$

$\begin{array}{ll}\text { Understanding stress } & 126\end{array}$

Management information $\quad 128$

$\begin{array}{lr}\text { Mentoring } & 129\end{array}$

$\begin{array}{lr}\text { Training schemes } & 129\end{array}$

$\begin{array}{ll}\text { Effective communication } & 130\end{array}$

Part III Practical Telebusiness and the Telemarketeer

8 Reactive or Proactive?

Inbound or outbound? 135

$\begin{array}{ll}\text { Auditing } & 136\end{array}$

$\begin{array}{ll}\text { Procedures } & 145\end{array}$

A marketing plan $\quad 148$

Follow through $\quad 150$

9 Image Projection and Telephone Etiquette 152

$\begin{array}{ll}\text { Being an ambassador } & 152\end{array}$

Telephone service $\quad 153$

A key to customer loyalty $\quad 156$

$\begin{array}{ll}\text { Exhibitions } & 162\end{array}$

No thank you! $\quad 164$

$\begin{array}{ll}\text { Not just a computer entry } & 164\end{array}$

10 Buying Behaviour 165

The Pareto principle $\quad 165$

$\begin{array}{ll}\text { Intangible factors } & 166\end{array}$

$\begin{array}{ll}\text { Business to business } & 167\end{array}$ 
Conditions and influences 168

$\begin{array}{ll}\text { Competitor analysis } & 170\end{array}$

11 Scripts and other things 172

$\begin{array}{ll}\text { To script or not to script? } & 173\end{array}$

$\begin{array}{ll}\text { Homeworking } & 173\end{array}$

$\begin{array}{ll}\text { Written communication } & 173\end{array}$

$\begin{array}{ll}\text { Debt collection } & 176\end{array}$

12 Telesales 179

$\begin{array}{ll}\text { How to sell } & 179\end{array}$

$\begin{array}{ll}\text { Buying criteria } & 180\end{array}$

$\begin{array}{ll}\text { Needs identification } & 182\end{array}$

$\begin{array}{ll}\text { A good listener } & 185\end{array}$

$\begin{array}{ll}\text { Selling solutions } & 186\end{array}$

$\begin{array}{ll}\text { Handling objections } & 188\end{array}$

$\begin{array}{ll}\text { 'Closing' } & 193\end{array}$

$\begin{array}{ll}\text { Attitude } & 195\end{array}$

$\begin{array}{ll}\text { Negotiation } & 196\end{array}$

Annexes

A A paper on stress management and depression, B. L. Corfield 199

B Standards and Regulations 203

The ISO 9000 standard 203

White Paper presentation for DMA telephone marketing 205

$\begin{array}{ll}\text { Regulations and regulatory bodies } & 210\end{array}$

C Example Forms 211

D Case Studies $\quad 224$

Bibliography and Further Information $\quad 229$

$\begin{array}{ll}\text { Index } & 233\end{array}$ 


\section{List of Tables and Figures}

TABLES

5.1 A manager's feelings and staff response

6.1 Performance standards 92

FIGURES

7.1 The motivation-hygiene theory 106

9.1 Three stages of counselling 158 


\section{Preface}

It is predicted that by the year 2000 , the UK Telebusiness market alone will be worth $£ 10$ billion and 2 million people will be working in it. Telebusiness is such a vast and growing area that you will find most books written about it tend to specialise in various aspects. For example, recent publications tend to concentrate upon the technological innovations and developments which allow us through computer integration to improve business by telephone. Others will cover specific marketing techniques related to telebusiness. These books, by specialisation and possibly assumption, exclude a breadth of knowledge and understanding in other areas. This book does not.

Whilst not claiming to be a specialised work, this book sets out to cover the breadth (and where possible the depth) of most subjects required to successfully introduce, manage and perform telebusiness.

Many related aspects of marketing including strategy, planning, database and relationship marketing are explored. Information technology resources are discussed through explanation of automation, telemarketing and innovations such as CTI (Computer Telephony Integration). Activities associated with the telephone including major account management, product life cycles, information flow and project management comprise the business management section of the book. People management material such as customer service, teamwork, motivation and recruitment are included with a dedicated section on telephone selling techniques for practitioners. Example forms, mentoring, stress management, buying behaviour, debt collection and case studies contribute to the breadth of subjects required for Total Telebusiness Management.

As a management consultant and sales trainer, most of the companies with whom I work at my entry point, aren't getting it right. Assisting these organisations to achieve bench mark productivity increases, staff with enhanced skills, and improved service levels has given me the opportunity to view both ends of a spectrum. Thus this book has been 
written from an experiential perspective and encompasses practical and realistic knowledge in all aspects of organisational and individual growth.

Much debate centres around Telecomms and IT convergence calling conventional management principles and techniques into question. Whilst I don't doubt the validity of progress, my work daily proves that people do not change. They hurt, aspire and excel in a variety of ways which as human emotions, remain unaffected by advances in technology. Voice processing techniques, number and line identification technologies, caller ID services, predictive dialling, fax processing, feature control and media conversion do save operator time, improve competitive advantage and enhance business processes. But they do not replace fundamental people management techniques which in turn are responsible for decreasing staff turnover, inspiring above average performance and creating loyal, motivated and customer orientated personnel.

You must decide for yourself whether improved systems and resources can replace people. 


\section{Acknowledgments}

My thanks go to Norman Hart who made the first approach. to Liz Robertson of Matrix Workstations and Phillipa Tozer of Market Solutions who were the only people to respond to my invitations, to Market Solutions again and Co Cam who provided the case studies, to B.L. Corfield for letting me print his paper, to John Strafford, Colin Grant, Fred Sheard, Neal McGuinness, Bill Woods and Ray Farmer who gave me confidence years ago, to all my clients and especially to the old pre-sales team at BT's Managed Network Services, Apsley, who let me view their projects.

Whilst writing this book, I developed a presently incurable and most distressing ear complaint called Tinnitus. I am grateful to Edward J.J. for his patience, sense of humour, knowledge, support and encouragement especially during the bad times.

VALERIE O'DeA 